\title{
Genotoxicity evaluation of pesticide profenofos by applying dominant lethal test on Culex quinquefasciatus
}

\author{
Preety B hinder* and A sha Chaudhry \\ Department of Zoology, Panjab University, Chandigarh-160014, INDIA \\ *Corresponding author. E-mail: preety.bhinder@yahoo.com
}

\begin{abstract}
The present paper deals with the genotoxicity evaluation of profenofos by applying dominant lethal test (DLT) on Culex quinquefasciatus taken as an experimental model. For this, the males hatched from the larvae treated with $\mathrm{LC}_{20}$ of pesticide were crossmated with normal females and the results were based on the number of hatched and unhatched eggs laid by these females. Mean percentage frequency of unhatched eggs was as low as 3.97 in the normal stocks as compared to treated stocks in which the frequency of unhatched eggs had increased to 9.50 . The statistical analysis of the data from treated groups gave values of $9.50 \pm 1.35$ as against $3.97 \pm 0.38$ in the control groups. Profenofos induced significant $(p<0.05)$ dominant lethality.
\end{abstract}

Keywords: Profenofos, Dominant lethal test, Cx. quinquefasciatus

\section{INTRODUCTION}

Organophosphorus insecticides are among the most frequently used pesticides in agricultural practices to boost the output. In addition, they are also used in forestry, horticulture, public health programmes and houses. Out of a large number of organophosphate pesticides, profenofos is one of most widely used pesticides as it is a broad spectrum, nonsystemic foliar insecticide and acaricide. Like most other pesticides, it effects on nontarget organisms including man is unavoidable. As a result of this, a variety of morphological, reproductive, hormonal, enzymatic and genotoxic effects of this pesticide have been reported (Fahmy and Abdalla, 1998; Venkateswara Rao, et al., 2003, 2006; Reddy and Venkateswara Rao, 2008; Kavitha and Venkateswara Rao, 2009; Li et al., 2010). In the recent years, a number of in vivo and in vitro methods have been employed to evaluate the genotoxic potential of such environmental mutagens (Evan, 1977; Gaulden and Liang, 1982; Loomis and Hayes, 1996; Crumpton et al., 2000; De Wolf et al., 2004; Atienzar and Jha, 2006; Naravaneni et al., 2006, Chaudhry et al., 2007; Chaudhry and Bhinder, 2009). Among them, dominant lethal test (DLT) is one such in vivo method which is used for evaluating the harmful effects of physical and chemical mutagens on the progenies of the treated parents on the basis of the frequency of viable and nonviable embryos produced from the effected parents (Suter, 1975; Sharma et al., 1989; Manna and Sarkar, 1998; Chaudhry and Anand, 2004; Chaudhry and Lovleen, 2008, 2010; Chaudhry et al., 2009). In the present investigations, mosquito Culex quinquefasciatus Say was taken as a test organism as it can be easily reared in the laboratory conditions, has short life cycle and lays eggs in groups (egg rafts) in which it is convenient to examine all the eggs laid by an individual. In reference to this, the present study was aimed to evaluate the genotoxicity of profenofos.

\section{MATERIALS AND METHODS}

Gravid females of Culex quinquefasciatus were collected from the cattle sheds in the village complex of Nadasahib, $20 \mathrm{kms}$ South-east of Chandigarh. They were allowed to lay eggs in water filled petridishes placed in the breeding cages after which these eggs were allowed to hatch and a colony of larvae and adults was raised under suitable conditions of temperature and humidity in the mosquito rearing laboratory (Asahina, 1964; Krishnan, 1964; Singh et al., 1975; Clements, 1996). Profenofos is a broad spectrum, non-systemic foliar insecticide and acaricide which is effective against wide range of chewing and sucking insects and mites. With solubility in water, its molecular formula is $\mathrm{C}_{11} \mathrm{H}_{15} \mathrm{BrClO}_{3} \mathrm{PS}$, molecular weight 373.63 and CAS number is $41198-08-7$. The larvae were treated with $\mathrm{LC}_{20}$ of the pesticide for which this concentration was calculated by applying probit analysis (Finney, 1971). Accordingly, early fourth instar larvae were treated with $5.19 \mu \mathrm{l} / \mathrm{ml}$ profenofos by rearing them in pesticides containing distilled water for 24 hours after which the treated larvae were transferred to pesticide free water for further development. Parallel controls were also maintained under similar conditions. Treated males were crossmated with virgin nontreated females (Muro and Goyer, 1969) after which the males were discarded 
while the females were fed on the blood of mice by holding the mice in a restrainer cage kept in the breading cages containing the experimental stocks. After three to four days the females laid eggs in water filled petridishes placed in the cages. These eggs were carefully examined under suitable magnification and the eggs with open opercula were considered as hatched while those with closed opercula were taken as unhatched (Figs. 1, 2). The number of unhatched eggs was taken as a criterion for calculating the dominant lethality in which the percentage frequency of induced dominant lethality was measured by applying the following formula:

Percentage frequency of unhatched eggs $=$ No. of unhatched eggs in one egg raft $\times 100 /$ Total number of eggs in the egg raft

This experiment was carried out in triplicate and the results were analyzed statistically by applying the Student's t-test for determining the level of significance of profenofos induced genotoxicity.

\section{RESULTS AND DISCUSSION}

In the present set of experiments, five egg rafts each of control and treated individuals were examined for the number of hatched and unhatched for evaluating the percentage frequency of nonviable eggs (Tables 1 and 2). On an average each egg raft contained 172 eggs in the control groups out of which 165 hatched while 7 remained unhatched whereby the frequency of unhatched eggs was approximately 3.17 (Table 1 ). When the same criterion was employed for the eggs laid by the females crossmated with profenofos treated males, the average number of eggs laid was 163 out of which hatched 147 while 16 remained unhatched. With this, the percentage frequency

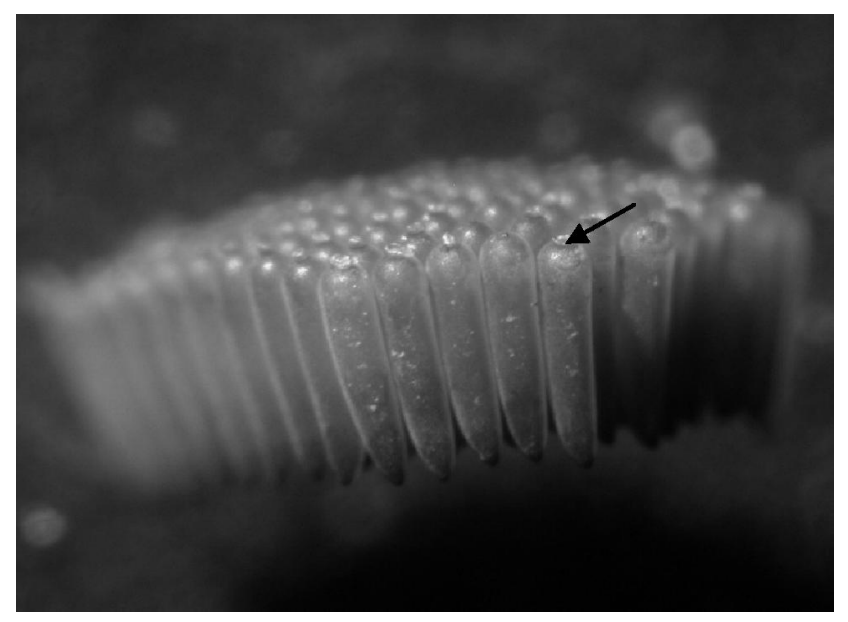

Fig. 1. Egg raft of $C x$. quinquefasciatus having unhatched eggs with closed operculum $(\rightarrow)$.

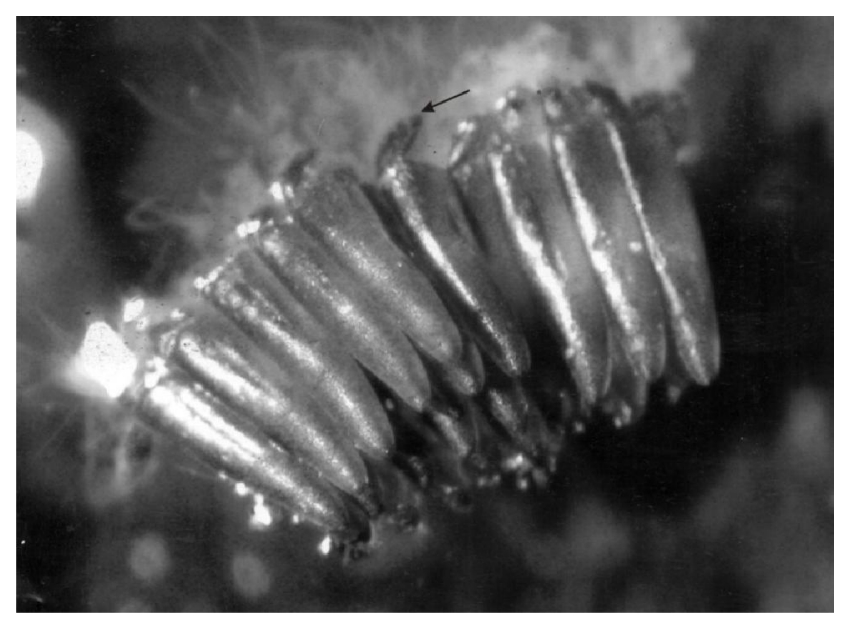

Fig. 2. Egg raft of $C X$. quinquefasciatus having hatched eggs with open operculum $(\rightarrow)$.

Table 1. Dominant lethality in the control stocks of $\mathrm{Cx}$. quinquefasciatus.

\begin{tabular}{lcccc}
\hline $\begin{array}{l}\text { No. of } \\
\text { egg raft }\end{array}$ & $\begin{array}{c}\text { Total no. of } \\
\text { eggs in an egg } \\
\text { raft }\end{array}$ & $\begin{array}{c}\text { N o. of hatched eggs } \\
\text { in each egg raft }\end{array}$ & $\begin{array}{c}\text { No. of unhatched } \\
\text { eggs in each egg } \\
\text { raft }\end{array}$ & $\begin{array}{c}\text { Percentage frequency } \\
\text { of unhatched eggs }\end{array}$ \\
\hline 1 & 184 & 176 & 8 & 4.34 \\
2 & 200 & 190 & 10 & 5.00 \\
3 & 150 & 146 & 4 & 2.66 \\
4 & 156 & 150 & 6 & 7 \\
5 & 174 & 167 & 7.84 & 4.02 \\
\hline
\end{tabular}

Table 2. Dominant lethality in the profenofos treated stocks of $C x$. quinquefasciatus.

\begin{tabular}{ccccc}
$\begin{array}{l}\text { No. of } \\
\text { egg raft }\end{array}$ & $\begin{array}{c}\text { Total no. of } \\
\text { eggsinan egg } \\
\text { raft }\end{array}$ & $\begin{array}{c}\text { No. of hatched eggs } \\
\text { in each egg raft }\end{array}$ & $\begin{array}{c}\text { No. of unhatched } \\
\text { eggs in each egg } \\
\text { raft }\end{array}$ & $\begin{array}{c}\text { Percentagefrequency } \\
\text { of unhatched eggs }\end{array}$ \\
\hline 1 & 140 & 128 & 12 & 8.57 \\
2 & 125 & 117 & 8 & 6.4 \\
3 & 150 & 139 & 11 & 7.33 \\
4 & 176 & 152 & 24 & 13.63 \\
5 & 224 & 198 & 26 & 11.60 \\
\hline
\end{tabular}


Table 3. Statistical data of dominant lethality in the control and profenofos treated stocks of $C x$. quinquefasciatus.

\begin{tabular}{ccccc}
\hline Type of Tarval stock & $\begin{array}{c}\text { Number of egg } \\
\text { rafts }\end{array}$ & $\begin{array}{c}\text { M ean Percentage } \\
\text { frequency of } \\
\text { un hatched eggs }\end{array}$ & M ean \pm SEM & $\begin{array}{c}\text { ' } t \text { ' value } \\
\text { (d.f. }=8 \text { ) }\end{array}$ \\
\hline Control & 5 & 3.97 & $3.97 \pm 0.38$ & $3.82^{*}$ \\
Treated & 5 & 9.50 & $9.50 \pm 1.35$ & \\
\hline
\end{tabular}

d.f. $=$ degree of freedom, SEM $=$ standard error of the mean, $*=$ significant $\mathrm{p}<0.05$

of unhatched eggs ranged between 6.4 to 13.63 (Table 2). These values were represented as mean \pm SEM (standard error of the mean) and the mean percentage frequency of unhatched eggs was as low as 3.97 in the normal stocks as compared to treated stocks in which the frequency of unhatched eggs had increased to 9.50. Accordingly, the percentage frequency of dominant lethality induced due to profenofos was found to be $9.50 \pm 1.35$ in treated as against $3.97 \pm 0.38$ in the control groups. From these values it was evident that significant $(\mathrm{p}<0.05)$ dominant lethality was induced by this pesticide (Table. 3 ). Dominant lethal test is an indirect expression of the genetic mutations in the germ cell chromosomes of the treated stocks in which the effect is generally expressed in the form of aberrant genotypes and phenotypes. When sublethal doses of environmental mutagens are administered to the sexually reproducing experimental organisms the induction of dominant lethal mutations in the reproductive cells of effected individuals donot usually hinder with the maturation of the treated cells into gametes which participate in the formation of a zygote. However, it does prevent the embryo from developing to maturity due to the death of the zygote at some stage between the formation of zygote and the production of adults. Bender et al. (1973, 1974) were of the opinion that the dominant lethality was the outcome of the loss of chromosomal material by way of deletions in the gametes leading to high frequency of damage to the male germ cell chromosomes and death of the early embryos. In some of the earlier studies, it was reported that profenofos induced chromosomal aberrations in somatic and germ cells of male mice (Fahmy and Abdalla, 1998). Moustafa et al. (2007) treated the male rats with profenofos after which they found abnormal expression of gene coding for steroidogenesis including cytochrome P450 17A1 (CYP17A1), steroidogenic acute regulatory protein (StAR) and CYP11A1. In the same specimen they also reported histological changes in the form of considerable destruction of testicular tissue while Farrag and Shalby (2007) reported that profenofos induced histopathological and histochemical effects in the liver and kidney tissues of rats. While studying the effect of this pesticide on gill morphology of fish, Oreochromis mossambicus, Venkateswara Rao et al. (2003) found abnormal gill morphology in the form of distinct breakage of gill arches and rakers along with deep lesions and

erosions in the epithelial cells. Reddy and Venkateswara Rao (2008) reported body ruptures, bloody lesions, excessive formation of glandular cell mass and disintegration of circular and longitudinal muscles in profenofos treated earthworm, Eisenia foetida while $\mathrm{Li}$ et al. (2010) reported significant DNA damage in the erythrocytes of profenofos treated tadpoles of Rana spinosa. In relevance to these reports, it may be added that the present results suggest that profenofos is a potential mutagen for the mosquito genome as it has induced significant dominant lethality and that, a dominant lethal test is a reliable means of demonstrating the toxic effect of a environmental mutagen on the reproductive potential of the effected individuals and its inheritance to the progenies of effected parents.

\section{ACKNOWLEDGEMENTS}

The authors are thankful to the Chairperson, Department of Zoology, Panjab University, Chandigarh for providing the necessary facilities to carry out the present research work under the Centre of Advance Studies (CAS) Programme of the University Grants Commission, New Delhi, India, Ref: F-5-4/2006(SAP-II), dated 7/12/2006, CAS Phase- I.

\section{REFERENCES}

Asahina, S. (1964). Food material and feeding procedures for mosquito larvae. Bull WH 0, 31: 465-466.

Atienzar, F.A. and Jha, A.N. (2006). The random amplified polymorphic DNA (RAPD) assay and related techniques applied to genotoxicity and carcinogenesis studies: A critical review. M utat. Res., 613(2-3) : 76-102.

Bender, M.A., Bedford, J.S. and Mitchell, J.B. (1973). Mechanisms of chromosome aberration production II. Aberrations induced by 5-bromodeoxyuridine and visible light. M utat. Res., $20: 403-416$.

Bender, M.A., Griggs, H.G. and Bedford, J.S. (1974). Mechanism of chromosomal aberration production III. Chemicals and ionizing radiation. M utat. Res., 23 : 197-212.

Chaudhry, A. and Anand, P.K. (2004). Assessment of dominant lethal effects of chlorpyrifos (CPF) using mosquito genetics. Poll. Res., 23 (4) : 767-771.

Chaudhry, A., Barna, B. and Sharma, M. (2007). rDNA ITS 2 sequence based genotoxicity evaluation of imidacloprid using mosquito genome (Culicidae: Diptera). J . Cytol. Genet., 8 : 85-92.

Chaudhry, A., Bansal, M. and Kaura, T. (2009). Dominant lethal test based genotoxicity evaluation of glyphosate in 
Culex quinquefasciatus. J. Cytol. G enet., 11: 23-30.

Chaudhry, A. and Bhinder, P. (2009). Cypermethrin induced mutations in rDNA internal transcribed spacers 1 and 2 of Culex quinquefasciatus (Diptera: Culicidae). J . Appl. B iosci., 35 (1) : 7-12.

Chaudhry, A. and Lovleen (2008). Evaluation of mutagenic potential of carbaryl by dominant lethal test on Culex quinquefasciatus. J. Cytol. G enet., 9(N.S): 37-44.

Chaudhry, A. and Lovleen (2010). Chromosomal aberrations and dominant lethal test based genotoxicity assessment of dicofol by using mosquito genome. J. C ytol. Genet., 11: 11-20.

Clements, A.N. (1996). The biology of mosquitoes. London: Chapman and Hall.

Crumpton, T.L., Seidler, F.J. and Slotkin, T.A. (2000). Developmental neurotoxicity of chlorpyrifos in vivo and in vitro: effects on nuclear transcription factors involved in cell replication and differentiation. Brain Res., 857 (12): 87-98.

De Wolf, H., Blust, R. and Backeljau, T. (2004). The use of RAPD in ecotoxicology. Mutat. Res., 556: 249-262.

Evan, H.S. (1977). M olecular mechanism in the induction of chromosome aberrations. In: D. Scott, B.A. Bridges and F.H. Sobels (Eds.). Progress in Genetic Toxicology (pp 5774), Amsterdam: Elseviser/North Holland Biomedical Press.

Fahmy, M.A. and Abdalla, E.F. (1998). Genotoxicity evaluation of buprofezin, petroleum oil and profenofos in somatic and germ cells of male mice. J . Appl. Toxicol., 18(5): 301-305.

Farrag, A.R.H. and Shalby, S.E.M. (2007). Comparative histopathological and histochemical studies on IGR, Lufenuron and Profenofos insecticide albino rats. J. Appl. Sci. Res., 3 (5): 377-386.

Finney, D.J. (1971). Probit analysis. Cambridge: Cambridge University Press.

Gaulden, M.E. and Liang, J.C. (1982). Insect cells for testing clastogenic agents. In: T.C. Hsu (Ed.). Cytogenetic Assays of Environmental Mutagens (pp107-135), NJ: Allanheld, Osmum.

Kavitha, P. and Venkateswara Rao, J. (2009). Sub-lethal effects of profenofos on tissue-specific antioxidative responses in a Euryhyaline fish, O reochromis mossambicus. E cotoxicol. Environ. Saf., 72: 1727-1733.

Krishnan, K.S. (1964). A note on colonization of Culex. Bull. WH 0, 31: 455-456.

Li, X., Li, S., Liu, S. and Zhu, G. (2010). Lethal effect and in vivo genotoxicity of profenofos to Chinese native amphibian
(Rana spinosa) tadpoles. Arch. Environ. Contam. Toxicol., 59: 478-483.

Loomis, T.A. and Hayes, A.W. (1996). Essentials of toxicology. $4^{\text {th }}$ ed. London: Academic Press.

Manna, G.K. and Sarkar, C.S. (1998). Mutagenic potential of the antifungal antibiotic grisefulvin to orally administered experimental mice and its follow-up in $\mathrm{F}_{1}$ and $F_{2}$ generations. Perspectives in Cytology and Genetics. AICCG-publi., Kalyani univ., Kalyani, India. p.383-398

Moustafa, G.G., Ibrahim, Z.S, Hashimoto, Y., Alkelch, A.M . Sakamoto, K.Q., Ishizuka, M. and Fujita, S. (2007). Testicular toxicity of profenofos in matured male rats. Arch. Toxicol., 81(12): 875-81.

Muro, L.A. and Goyer, R.A. (1969). Chromosome damage in experimental lead poisoning. Arch. Pathol., 87: 660663.

Naravaneni, R., Suman, G. and Jamil, K. (2006). In vitro cytogenetic studies of cypermethrin on human lymphocytes. Indian J. Exp. Biol., 44(3): 233-239.

Reddy, N.C. and Venkateswara Rao, J. (2008). Biological response of earthworm, Eisenia foetida (Savigny) to an organophosphorous pesticide, profenofos. Ecotoxicol. Environ. Saf., 71: 574-582.

Sharma, G.P., Sobti, R.C., Chaudhry, A. and Ahluwalia, K.K. (1989). Chromosomal aberrations and dominant lethal in Culex fatigans due to mercuric chloride. Cytobios, 59: 131135.

Singh, K.R.P., Patterson, R.S., La-Brecque, G.C. and Razdan, R.K. (1975). Mass rearing of Culex pipiens fatigans Weid. J. Com. Dis., 7: 31-53.

Suter, K.E. (1975). Studies on the dominant lethal and fertility effects of the heavy metal compounds methylemercuric hydroxide, mercuric chloride and cadmium chloride in the male and female mice. M utat. Res., 30: 365-374.

Venkateswara Rao, J., Begum, G., Jakka, N.M., Srikanth, K. and Nageswara Rao, R. (2006). Sublethal effects of profenofos on locomotor behavior and gill architecture of the mosquito fish, $\mathrm{G}$ ambusia affinis. Drug Chem. Toxicol., 29 (3) : 255-267.

Venkateswara Rao, J., Shilpanjali, D., Kavitha, P. and Madhavendra, S.S. (2003). Toxic effects of profenofos on tissue acetylcholinesterase and gill morphology in a euryhaline fish, O reochromis mossambicus. Arch. Toxicol., 77(4): 227-232. 